\title{
Antibacterial activity of ethanolic extract and compounds from fruits of Tectona grandis (Verbenaceae)
}

\author{
Gabin Thierry M. Bitchagno ${ }^{1}$, Leonard Sama Fonkeng², Théodora K. Kopa ${ }^{1,3}$, Michel F. Tala', \\ Hippolyte Kamdem Wabo ${ }^{1}$, Christopher B. Tume ${ }^{2}$, Pierre Tane ${ }^{1}$ and Jules-Roger Kuiate ${ }^{1 *}$
}

\begin{abstract}
Background: Well known as teak, Tectona grandis is widely used in African folk medicine for its pharmacological relevance. In Cameroon, this species is a reputed laxative in the Northern Region while in the Western Region, it is used in the treatment of skin diseases and diarrhoea.

Materials and methods: Separation and isolation of compounds were performed using different chromatographic methods while their structures were elucidated by spectroscopic techniques including MS and NMR, and by comparison of data with those reported in the literature. Isolated compounds as well as crude ethanol extract were tested for their antibacterial activities using broth micro-dilution method against four Gram negative bacteria strains Escherichia coli (ATCC 8739), Pseudomonas aeruginosa (PA 01), Klebsiella pneumonia (ATCC 11296) and Escherichia aerogenes (ATCC 13048).

Results: Three known compounds were isolated, including two quinones and one triterpene. They were identified as tectograndone (1), 6-methyl-1,4-dihydroxyanthraquinone (2), and 2 $\beta$-hydroxyursolic acid (3) respectively. Crude ethanol extract showed good activity against the bacteria strains tested with MIC of $64-256 \mu \mathrm{g} / \mathrm{mL}$. Among the isolated metabolites, 6-methyl-1,4-dihydroxyanthraquinone exhibited a strong activity against Escherichia aerogenes with MIC of $16 \mu \mathrm{g} / \mathrm{mL}$, while tectograndone showed a moderate activity against Escherichia coli with MIC of $32 \mu \mathrm{g} / \mathrm{mL}$. The antibacterial screening of the fruits of this plant as well as that of compounds 1 and 2 is reported herein for the first time.
\end{abstract}

Conclusion: The research work presented here shows that Tectona grandis fruits possess compounds which could be developed in the treatment of bacterial diseases.

Keywords: Tectona grandis, Fruits, Quinones, Terpenoids, Antibacterial

\section{Background}

Tectona grandis Linn. is a large tree from Southeast Asia which grows up to $50 \mathrm{~m}$ in height. It is the most important species of the genus Tectona [1] and has been naturalized in Africa. Well known as teak, T. grandis is widely reputed for its strong and straight trunk which is used in the construction industry. Traditionally, this species is globally used to relieve fever, diabetes, lipid disorders, ulcers, inflammation, bronchitis, cancer and

\footnotetext{
* Correspondence: jrkuiate@yahoo.com

${ }^{1}$ Department of Chemistry, University of Dschang, P.O. Box 67, Dschang, Cameroon

Full list of author information is available at the end of the article
}

tuberculosis [2, 3]. In the Northern part of Cameroon, leaves of teak are used for their laxative properties while in the Western Region, it is used for the treatment of skin diseases. Previous phytochemical investigation of Tectona species have led to the isolation of triterpenoids, flavonoïds [4], chromomoric acid derivatives [5], anthraquinones [6-8], naphthoquinones $[9,10]$, anthraquinone-naphthoquinones $[11,10]$, apocarotenoids [1] and lignans [12]. Some of these metabolites particularly the quinines showed antimycobacterial, antifungal and allelopathic activities $[7,9,11,1,10]$. In the course of our ongoing search for potent bioactive compounds from Cameroonian medicinal plants $[6,13,14]$, we carried out

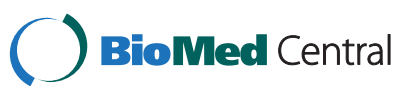


the chemical investigation of the fruit of $T$. grandis and report herein the antibacterial properties of compounds isolated from the ethanolic extract.

\section{Methods}

\section{General experimental procedures}

Melting points of the isolated compounds were determined using an Electrothermal IA9000 Series digital melting point apparatus (Bibby Scientific, Great Britain). MS detection was carried out using a Waters Micromass ESI-Q-TOF II instrument with ESI ionization in the positive mode. EIMS spectra were recorded on a Finnigan MAT 95 spectrometer $(70 \mathrm{eV})$ with perfluorokerosine as reference substance for HR-ESI-TOF-MS (Japan). IR spectra were recorded on a Shimadzu FTIR8400 S spectrophotometer (Japan). UV spectra were recorded on a Shimadzu UV-160A spectrometer (Japan) in absolute ethanol and alkaline ethanol. The NMR spectra were measured on Bruker $500 \mathrm{MHz}$ NMR Avance II spectrometer equipped with cryoprobe, with TMS as an internal reference. Chemical shifts were recorded in $\delta$ $(\mathrm{ppm})$ and the coupling constants $(J)$ are in hertz $(\mathrm{Hz})$. Silica gel $60 F_{254}$ (70-230; Merck; Darmstadt, Germany) was used for column chromatography. Precoated silica gel Kieselgel $60 F_{254}$ plates $(0.25 \mathrm{~mm}$ thick) were used for TLC, and spots detected by spraying with $50 \%$ $\mathrm{H}_{2} \mathrm{SO}_{4}$ followed by heating at $100{ }^{\circ} \mathrm{C}$.

\section{Plant material}

The fruits of $T$. grandis were collected in Banyo, Adamaoua Region of Cameroon in January 2011. The species was identified at the Cameroon National Herbarium (Yaoundé), by comparing with a voucher specimen No. 61993 HNC.

\section{Extraction and fractionation}

Dried fruits of Tectona grandis $(2.5 \mathrm{Kg})$ were extracted with ethanol $(10 \mathrm{~L})$ for $72 \mathrm{~h}$ at room temperature to yield a crude extract (55 g) after evaporation under reduced pressure. This extract $(50 \mathrm{~g})$ was subjected to silica gel column chromatography eluted with gradients of $n$-hexane-EtOAc and EtOAc-MeOH. Ninety fractions of $300 \mathrm{~mL}$ each were collected using mixtures of $\mathrm{n}$-hexaneEtOAc 85:15, 70:30, 30:70 and combined on the basis of their TLC profiles into four main fractions coded A-D (A: 1-19; B: 20-46; C: 47-68; D: 69-90). Fraction A $(20 \mathrm{~g})$ contained mostly fatty material and was not further investigated. Fraction B (6.5 g) was separated by a column chromatography over silica gel using a gradient of $n$-hexane-EtOAc (100:0, 95:5, 90:10, 85:15, 80:20, 75:25 and 70:30) to afford five sub-fractions (FrB1-FrB5). Following their TLC profiles, only FrB3 was retained for further purification over silica gel column chromatography with $n$-hexane-EtOAc to afford $2 \beta$-hydroxyursolic acid (3) (10 mg). Fraction C (10 g) was subjected to column chromatography over silica gel eluted with $n$-hexane-EtOAc (90:10, 85:15, 80:20, 75:25 and 70:30). The collected fractions which contained the major compound 6-methyl-1,4-dihydroxyanthraquinone (2) were combined and applied on a Sephadex LH-20 column (n-hexane-dichloromethane-methanol, 7:4:0.5) to give $8 \mathrm{mg}$ while the remaining complex material was kept aside for further investigation. Similary, repeated column chromatography of fraction D (2 g) yielded tectograndone (1) (8 mg).

Tectograndone (1): Red powder in acetone, ${ }^{13} \mathrm{C}$ NMR $\left(\mathrm{CDCl}_{3}-\mathrm{DMSO}-d_{6}, 125 \mathrm{MHz}\right) \delta(\mathrm{ppm}): 187.5\left(\mathrm{C}-1^{\prime}\right)$, 185.5 (C-6), 183.8 (C-11), 188.2 (C-4'), 157.9 (C-8'), 157.2 (C-5'), 155.8 (C-5), 150.7 (C-12a), 149.0 (C-12), 145.7 (C-8), 138.4 (C-9), 135.6 (C-2'), 132.4 (C-10), 132.3 (C-3), 131.5 (C-6'), 130.2 (C-10a), 128.9 (C-7), 128.1 (C-7'), 126.6 (C-3'), 125.8 (C-6a), 117.0 (C-4a), 115.7 (C-4), 113.4 (C-11a), 111.6 (C-4a'), 79.8 (C-2).

6-methyl-1,4-dihydroxyanthraquinone (2): Red powder in acetone, ${ }^{13} \mathrm{C}$ NMR (DMSO- $\left.d_{6}, 125 \mathrm{MHz}\right) \delta(\mathrm{ppm})$ : 186.6 (C-9), 186.3 (C-10), 156.6 (C-1), 156.6 (C-4), 146.0 (C-6), 135.6 (C-7), 132.6 (C-5a), 130.4 (C-8a), 129.2 (C-2), 129.1 (C-3), 126.6 (C-5), 126.6 (C-8), 112.6 (C-4a), 112.4 (C-9a).

$2 \beta$-hydroxyursolic acid (3) :White powder in $\mathrm{MeOH}$, ${ }^{13} \mathrm{C}$ NMR (DMSO- $\left.d_{6}, 125 \mathrm{MHz}\right) \delta(\mathrm{ppm}): 178.1(\mathrm{C}-28)$; 138.2 (C-13); 124.4 (C-12); 79.0 (C-3); 64.5 (C-2); 52.3 (C-5); 47.5 (C-18); 46.8 (C-1); 46.7 (C-17); 41.6 (C-9); 40.1 (C-14); 39.9 (C-4); 38.4 (C-8); 38.3 (C-20); 37.8 (C-19); 37.6 (C-10); 36.2 (C-22); 32.5 (C-7); 30.1 (C-21); 28.7 (C-23); 27.3 (C-15); 23.7 (C-16); 23.2 (C-27, C-11); 22.8 (C-30); 20.9 (C-6); 17.5 (C-24); 16.8 (C-26, C-29); $16.4(\mathrm{C}-25)$.

The qualitative analysis of the ethanol extract of the teak fruit was also conducted by using the method described by Harbone (1973) [15] with slight modifications.

\section{Antibacterial assay \\ Microorganisms}

Microorganisms used in this study were four Gramnegative bacteria strains Escherichia coli (ATCC 8739), Pseudomonas aeruginosa (PA 01), Klebsiella pneumonia (ATCC 11296) and Escherichia aerogenes (ATCC 13048) all of which were reference strains obtained from the American Type Culture Collection. The bacterial strains were grown at $35{ }^{\circ} \mathrm{C}$ and maintained on Mueller Hinton Agar (MHA) (Titan Biotech Ltd Rajasthan India).

\section{Preparation of inoculum}

The inoculum was prepared as described by Tereshuck et al. [16] from $24 \mathrm{~h}$ old cultures by picking numerous colonies and suspending them in sterile saline $(\mathrm{NaCl}, 0.9 \%)$ 
solution. Absorbance was read at $530 \mathrm{~nm}$ and adjusted with the saline solution to match to that of a $0.5 \mathrm{McF}$ arland standard solution, corresponding to about $1.5 \times 10^{8}$ Colony Forming Units (CFU).

\section{Preparation of extract and determination of Minimum Inhibitory Concentrations (MICs) and Minimum Bactericidal Concentration (MBCs)}

The antibacterial activity was investigated by determining the minimum inhibitory concentrations (MICs) and the minimum bactericidal concentrations (MBCs). MICs were determined by a broth micro-dilution method with slight modification of the method described by Newton et al. (2012) [17].

Stock solutions of the extract and compounds were prepared in the Mueller Hinton Broth (MHB) (Titan Biotech Ltd Rajasthan India) in $5 \%$ ( $/ \mathrm{V}$ ) dimethylsulfoxide (DMSO) solution (Fisher chemicals, Strasbourg, France) for a final concentration of $4096 \mu \mathrm{g} / \mathrm{mL}$ and $1024 \mu \mathrm{g} / \mathrm{mL}$ respectively for extract and compounds.

Into each well of 96-microplate (Nunclon, Roskilde, Denmark) $100 \mu \mathrm{L}$ of $\mathrm{MHB}$ and $100 \mu \mathrm{L}$ of the test substance solution were introduced. Twofold were serial dilutions was made to obtain a concentration range of
$8-1024 \mu \mathrm{g} / \mathrm{mL}$ for crude extract and $8-256 \mu \mathrm{g} / \mathrm{mL}$ compounds. Bacterial inoculums $(400 \mu \mathrm{L})$ prepared above was added to MHB (15 mL) for a final concentration of $4 \times 10^{6} \mathrm{CFU} / \mathrm{mL}$ which was used for this test. One hundred microliters of this inoculum was introduced to each well containing $100 \mu \mathrm{L}$ of $\mathrm{MHB}$ and extract mixture to a final volume of $200 \mu \mathrm{L}$. The final concentration of DMSO in the well was less than $1 \%$ (preliminary analyses show that $1 \%(\mathrm{v} / \mathrm{v})$ DMSO does not inhibit the growth of the test organisms). A sterility check (5\% DMSO, media, inoculum and water soluble antibiotic) was included in the experiment. The plates were covered with a sterile lid, and incubated at $35{ }^{\circ} \mathrm{C}$ for $24 \mathrm{~h}$ under shaking using a plate shaker (Flow Laboratory Germany) at $300 \mathrm{rpm}$. After this incubation, the MICs were assessed by adding $40 \mu \mathrm{L}$ of $2 \%$ solution of p-iodonitrotétrazolium (INT) (Sigma-Aldrich, South Africa) in each well. Viable bacteria cause the appearance of pink coloration in the presence of this solution [18]. The concentration that did not show the appearance of pink solution was considered as the inhibition concentration and the smallest one was noted as the MIC. For the well that did not present color changes, $50 \mu \mathrm{L}$ aliquots of solution of the corresponding well which did not receive<smiles>Cc1cc2c(c(C3=CC(=O)c4c(O)ccc(O)c4C3=O)c1)C(=O)c1c(O)c3c(c(O)c1C2=O)OC(C)(C)C=C3</smiles><smiles>Cc1ccc2c(c1)C(=O)c1c(O)ccc(O)c1C2=O</smiles>

2

1

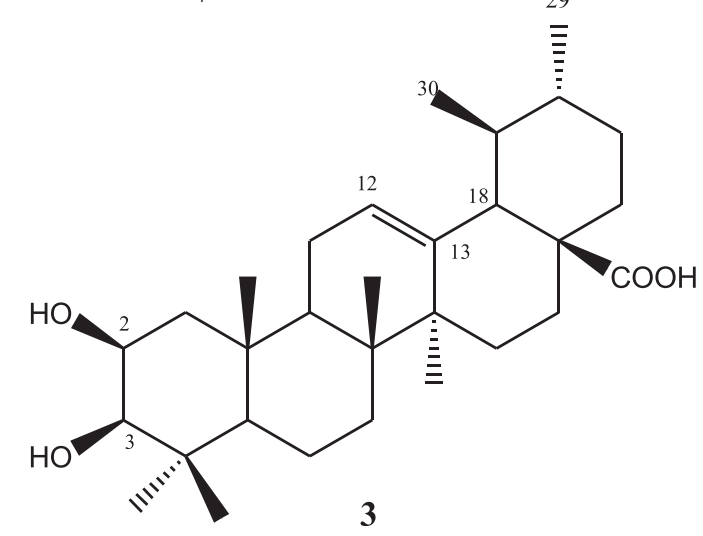

Fig. 1 Chemical structures of compounds $1-3$ 
Table 1 Phytochemical classes of compounds in the ethanol extract of the fruits of T. grandis

\begin{tabular}{lllllllll}
\hline & Flavonoid & Anthraquinone & Polyphenol & Sterol & Triterpen & Xanthocyanate & Tanin & Saponin \\
\hline Crude extract & - & + & + & + & + & - & & + \\
\hline$(-)$ absent $(+)$ & & + & + & & & + \\
\hline
\end{tabular}

(-)absent; (+) present

INT were put into the well of a new plate containing $150 \mu \mathrm{L}$ of freshly prepared MHB and re-incubated at $35{ }^{\circ} \mathrm{C}$ for $48 \mathrm{~h}$ on the shaker. After this re-incubation, $40 \mu \mathrm{L}$ of INT were introduced in each well and all the concentrations that did not present color change were considered as the bactericidal concentration and the smallest one was noted as MBC. The assay was repeated thrice. Ciprofloxacine at the concentration range of $0.039-5 \mu \mathrm{g} / \mathrm{mL}$ served as positive control.

\section{Results}

The structures of the isolated compounds were elucidated using modern spectroscopic methods (IR, ${ }^{1} \mathrm{H}$ and ${ }^{13} \mathrm{C}$ NMR, HRMS and 2D-NMR). Comparison of data with those reported in the literature led to the identification of the compounds as tectograndone (1) [11], $2 \beta$-hydroxyursolic acid (3) [19] and 6-methyl-1,4-dihydroxyanthraquinone (2) [20] (Fig. 1). Previous phytochemical investigation of teak leaves also led to the isolation of triterpenoids [4], anthraquinones [6-8] and naphthoquinones [9, 10].

\section{Phytochemical analysis}

In this study, the phytochemical composition of the fruits extract of $T$. grandis was evaluated and we investigated the antibacterial activity of extract together with isolated compounds investigated. Qualitatively, the crude extract contains anthraquinones, polyphenols, sterols, triterpenes and tannins but not flavonoïds, xanthocyanates and saponins (Table 1$)$.
Moreover, the results shown in Table 2 demonstrate that the ethanol extract of teak fruit displayed good activities against Escherichia coli (ATCC 8739), Pseudomonas aeruginosa (PA 01), Klebsiella pneumonia (ATCC 11296) and Escherichia aerogenes (ATCC 13048) with the MIC values ranging from 64 to $256 \mu \mathrm{g} / \mathrm{mL}$. The isolated compounds(1-3) showed potent antibacterial activity toward these microorganisms. This supports the use of this plant in traditional medicine in the treatment of skin diseases. Compounds $\mathbf{1}$ and 2, with the same basic quinoidal skeletal units, were the most active against E. coli $(32 \mu \mathrm{g} / \mathrm{mL})$ and E. aerogene $(16 \mu \mathrm{g} / \mathrm{mL})$ respectively. In addition, compound $\mathbf{2}$ also presented a considerable antibacterial activity against $P$. aeruginosa $(128 \mu \mathrm{g} / \mathrm{mL})$.

\section{Discussion}

It has been reported that the number and position of hydroxyl groups in phenolic compounds such as anthraquinones can significantly influence their antimircobial activity [14]. Generally, those possessing free hydroxyl group(s) display good activities. Some examples include physcion, emodin, and fallacinol $[21,22,14]$. Compound 3 showed a moderate antibacterial activity $(64-128 \mu \mathrm{g} / \mathrm{mL})$ against all tested bacteria. Previously, it had been shown that ursolic acid, a compound structurally related to $\mathbf{3}$ also exhibited moderate activity against $E$. coli but none toward $P$. aeruginosa [23]. All these isolated compounds $(\mathbf{1}, \mathbf{2}, \mathbf{3})$ showed antibacterial activity on at least one strain of

Table 2 Minimum inhibitory concentration and minimum bactericidal concentration $(\mu \mathrm{g} / \mathrm{mL})$ of the ethanol extract and compounds of the fruits of $T$. grandis

\begin{tabular}{|c|c|c|c|c|c|c|}
\hline Bacteria strains & Parameters & $\begin{array}{l}\text { EtOH } \\
\text { extract }\end{array}$ & Tectograndone (1) & 6-methyl-1,4-dihydroxyanthraquinone (2) & $\begin{array}{l}2 \beta \text {-hydroxyursolic } \\
\text { acid (3) }\end{array}$ & Ciprofloxacine $^{a}$ \\
\hline \multirow[t]{3}{*}{ Escherichia coli ATCC8739 } & MIC & 64 & 32 & $>256$ & 128 & 5 \\
\hline & $M B C$ & 128 & 128 & $>256$ & 256 & 5 \\
\hline & $\mathrm{MBC} / \mathrm{MIC}$ & 2 & 4 & - & 2 & 1 \\
\hline \multirow{3}{*}{$\begin{array}{l}\text { Pseudomonas aeruginosa } \\
\text { PA01 }\end{array}$} & MIC & 256 & $>256$ & 128 & 64 & 0.0625 \\
\hline & $\mathrm{MBC}$ & 256 & $>256$ & 256 & 128 & 0.0625 \\
\hline & $\mathrm{MBC} / \mathrm{MIC}$ & 1 & - & 2 & 2 & 1 \\
\hline \multirow{3}{*}{$\begin{array}{l}\text { Klebsiella pneumonia } \\
\text { ATCC1148 }\end{array}$} & MIC & 128 & $>256$ & $>256$ & 64 & 5 \\
\hline & $M B C$ & & $>256$ & $>256$ & 128 & 5 \\
\hline & $\mathrm{MBC} / \mathrm{MIC}$ & 2562 & - & - & 2 & 1 \\
\hline \multirow{3}{*}{$\begin{array}{l}\text { Escherichia aerogenes } \\
\text { ATCC13048 }\end{array}$} & MIC & 64 & $>256$ & 16 & 64 & 2.5 \\
\hline & $M B C$ & 128 & $>256$ & 128 & 128 & 2.5 \\
\hline & $\mathrm{MBC} / \mathrm{MIC}$ & 2 & - & 8 & 2 & 1 \\
\hline
\end{tabular}

${ }^{a}$ Reference drug 
bacteria together while the crude extract which presented high activity against all the bacteria strains. Some individual anthraquinones, tannins, polyphenols, sterols and triterpenes have shown similar types of biological activities [24-30]. Their synergic effect was also reported [31].

Our data showed that the response of the bacteria to the tested compounds varied from one microorganism to another. This difference in susceptibility may be explained by the difference in cell wall composition and/or genetic content of plasmids that can be easily transferred amount microbial strains [32]. It was also found that $\mathrm{MBC}$ values obtained were generally less than fourfold of their MICs values (Table 2) on the bacteria species. This suggests that a bacteriocidal effect of the crude extract and the isolated compounds could be expected on most the tested bacteria [33,34]. This is interesting in view of the prospect of developing new antibacterial drugs from the tested samples. To the best of our knowledge, this is the first report on the antibacterial activity of the crude extract and compounds from fruit of $T$. grandis.

The overall results of this study can be considered promising in view of the need to develop of new phytodrugs for the fight against bacterial infections of public health importance. P. aeruginosa has emerged as one of the most problematic Gram-negative pathogens, with an alarmingly high antibiotic resistance rate [35, 36]. Even with the most effective antibiotics against this pathogen, namely the carbapenems (imipenem and meropenem), the level of resistance was found to be about 15-20.4\% among the 152 tested $P$. aeruginosa strains [36]. This pathogen was found to be sensitive to the crude extract and two of the isolated compounds $(\mathbf{1}, \mathbf{2})$.

\section{Conclusion}

The results of the present study provide an important basis for use of the ethanol extract from the fruits of $T$. grandis for the treatment of skin diseases. The crude extract as well as the isolated compounds found to be active in this study could also be useful for the development of new antibacterial drugs. However, further pharmacological and toxicity studies currently going on in our laboratory will be necessary to establish if they could be safely used as topical antibacterial agents.

\section{Competing interests}

The authors declare that they have no competing interests.

\section{Authors' contributions}

GTMB, LSF and TKK were field investigators and drafted the manuscript. MFT participated in the experiments, the interpretation of the NMR data and the correction of the manuscript. HKW and CBT designed the study and finalized the manuscript, HL participated in NMR measurements and NMR data analysis and PT and J-RK supervised the work. All authors read and approved the final manuscript.

\section{Acknowledgements}

We are grateful to the University of Dschang for financing some consumables used in this work. We also gratefully acknowledge the financial support to MFT by the German Academic Exchange Service (DAAD, Germany; grant no. A/10/90128).

\section{Author details}

'Department of Chemistry, University of Dschang, P.O. Box 67, Dschang, Cameroon. ${ }^{2}$ Department of Biochemistry, University of Dschang, P.O. Box 67, Dschang, Cameroon. ${ }^{3}$ Institute of Medical Research and Medicinal Plants Studies (IMPM), P.O. Box 6163, Yaounde, Cameroon.

Received: 31 December 2014 Accepted: 21 July 2015

Published online: 06 August 2015

\section{References}

1. Macias FA, Lacret R, Varela RM, Nogueiras C, Molinillo JMG. Bioactive apocarotenoids from Tectona grandis. Phytochemistry. 2008;69:2708-15.

2. Rajuri A, Rao KNV, Banji D, Chaithanya RK. A review on Tectona grandis Linn: chemistry and medicinal uses (family: Verbenaceae). Herbal Tech Industry. 2010;1:6-9.

3. Warrier PS. Indian Medicinal Plants, 1st ed. Orient Longman Pvt. Ltd. New Delhi, India, 1194;pp. 245-48.

4. Ragasa CY, Lapina MC, Lee JJ, Mandia EH, Rideout JA. Secondary metabolites from Tectona philippinensis. Nat Prod Res. 2008;9:820-4.

5. Ragasa CY, Tepora MM, Espinelli DH, Mandia EH, Rideout JA. Chromomoric acid derivatives from Tectona philippinensis. J Nat Prod. 2008;71:701-5.

6. Kopa TK, Tchinda AT, Tala MF, Zofou D, Jumbam R, Wabo HK, et al. Antiplasmodial anthraquinones and hemisynthetic derivatives from the leaves of Tectona grandis (Verbenaceae). Phytochem Lett. 2014;8:41-5.

7. Sumthong P, Damveld RA, Choi YH, Arentshorst M, Ram AFJ, CAMJJ V d h, et al. Activity of quinones from Teak (Tectona grandis) on fungal cell wall stress. Planta Med. 2006;72:943-4.

8. Sumthong P, Romero-Gonzalez RR, Verpoorte R. Identification of anti-wood rot compounds in Teak (Tectona grandis L. f) Sawdust extract. J Wood Chem Technol. 2008;28:247-60.

9. Pradeep KG, Pahup S. A naphthoquinone derivative from Tectona grandis (Linn). J Asian Nat Prod Res. 2004;6:237-40.

10. Lacret R, Varela RM, Molinillo JMG, Nogueiras C, Macias FA. Anthratectone and naphthotectone, two quinones from bioactive extracts of Tectona grandis. J Chem Ecol. 2011;37(12):1341-8.

11. Aguinaldo AM, Ocampo OPM, Bowden BF, Gray Al, Peter G. Tectograndone, an anthraquinone-naphthoquinone pigment from the leaves of Tectona grandis. Phytochemistry. 1993;4:933-5.

12. Lacret R, Varela RM, Molinillo JMG, Nogueiras C, Macias FA. Tecto-noelins, new norlignans from bioactive extract of Tectona grandis. Phytochem Lett. 2012;5:382-6.

13. Tala MF, Krohn K, Hussain H, Kouam SF, Wabo HK, Tane P, et al. Laurentixanthone $C$ : A new antifungal and algicidal xanthone from stem bark of Vismia laurentii. Z. Natur forsch. 2007;62:565-8.

14. Tamokou JDD, Tala MF, Wabo HK, Kuiate JR, Tane P. Antimicrobial activities of methanol extract and compounds from stem bark of Vismia rubescens. J Ethnopharmacol. 2009;124:571-5.

15. Harbone JB. Phytochemical methods: A guide to modern techniques of plant analysis. London: Chapman and Hall Ltd; 1973. p. 116.

16. Tereshuck ML, Riera MVQ, Castro GR, Abdala LR. Antimicrobial Activity of flavonoid from leaves of Tagetes minuta. J Ethnopharmacol. 1997;56:227-32.

17. Newton SM, Lau C, Gurcha SS, Besra GS, Wright CW. The evaluation of forty-three plant species for in vitro antimycobacterial activities; isolation of active constituents from Psoralea corylifolia and Sanguinaria canadensis. J Ethnopharmacol. 2002;79:57-63.

18. Mativandlela SPN, Lall N, Meyer JJM. Antibacterial, antifungal and antitubercular activity of Pelargonium reniforme (CURT) and Pelargonium sidoides (DC) (Geraniaceae) root extracts. S Afr J Bot. 2006;72:232-7.

19. Mohammed Y, Javed K, Hasnain M. a-Amyrin derivatives from Corchorus depressus. Phytochemistry. 1991;30:1989-92.

20. Hua DH, Havens J, Perchellet EM, Wang Y, Lou K, Perchellet JP, et al. Synthesis and in vitro antitumor activity of substituted anthracene-1,4diones. Tetrahedron. 2004;60:10155-63.

21. Barros IB, de Souza-Daniel JF, Pinto JP, Rezende MI, Filho RB, Ferreira DT. Phytochemical and Antifungal Activity of Anthraquinones and Root and 
Leaf Extracts of Coccoloba mollis on Phytopathogens. Braz Arch Biol Technol. 2011;54:535-41.

22. Manojlovic TN, Solujic S, Sukdolak S. Antimicrobial activity of an extract and anthraquinones from Caloplaca schaereri. Lichenologist. 2002;34:83-5.

23. Wolska Kl, Grudniak AM, Fiecek B, Kraczkiewicz-Dowjat A, Kurek A. Antibacterial activity of oleanolic and ursolic acids and their derivatives. Central Eur J Biol. 2010;5:543-53.

24. Arunkumar S, Muthuselvam M. Analysis of phytochemical constituents and antimicrobial activities of Aloe vera $\mathrm{L}$. against clinical pathogens. World J Agri Sci. 2009;5:572-6.

25. Syed MMS, Farhat AK, Syed MHS, Kamran AC, Syed MSSP, Muhammad AK, et al. Evaluation of phytochemicals and antimicrobial activity of white and blue capitulum and whole plant of Silybum Marianum. World Appl Sci J. 2011;12:1139-44

26. Namuli A, Abdullah N, Sieo CC, Zuhainis SW, Oskoueian E. Phytochemical compounds and antibacterial activity of Jatropha curcas Linn extracts. J Med Plant Res. 2011:5:3982-90.

27. Sathya BS, Jayasurya KS, Sankaranarayanan S, Bama P. Antibacterial activity of different Phytochemical extracts from the leaves of T. Procumbens Linn.: identification and mode of action of the terpenoid compound as antibacterial. Inter J Pharm Pharm Sci. 2012;4:557-64.

28. Nyembo K, Kikakedimau N, Mutambel H, Mbaya N, Ekalakala T, Bulubulu O. In vitro antibacterial activity and phytochemical screening of crude extracts from Curcas Linn. Eur J Med Plant. 2012;2:242-51.

29. Mohamed ED, Hocine A, Bendiabdellah A, Meliani N, Boufeldja T. Antimicrobial activity and phytochemical screening of Arbutus unedo L. J Saudi Chem Soc. 2013;17:381-5.

30. Ramesa SB, Sooad A. Phytochemical constituents and antibacterial activity of some green leafy vegetables. Asian Pac J Trop Biome. 2014;4:189-93.

31. Gislene GGF, Locatelli J, Freitas PC, Silva GL. Antibacterial activity of plant extracts and phytochemicals on antibiotic-resistant bacteria. Braz Microbiol. 2000;31:247-56.

32. Karaman I, Sahin F, Gulluce M, Ogochu H, Sngul M, Adiguzel A. Antimicrobial activity of aqueous and methanol extract of Juniperus oxycedrus L. J Ethnopharmacol. 2003:85:231-5.

33. Carbonnelle B, Denis F, Marmonier A, Pinon G, Vague R. Bactériologie médicale: Techniques usuelles. SIMEP Paris. 1987. p. 228-82

34. Mims CA, Playfair JHL, Roitt IM, Wakelin D, Williams R. Antimicrobials and chemotherapy. Med Microbiol Rev. 1993:35:1-34.

35. Bacq-Calberg CM, Coyotte J, Hoet P, Nguyem-Disteeche M. Microbiologie. Bruxelles: De Boeck and Larcier; 1999. p. 338

36. Savafi L, Duran N, Savafi N, Onlem Y, Ocak S. The prevalence and resistance pattern of Pseudomonas aeruginosa in intensive care units in a university Hospital. Turk J Med Sci. 2005:35:317-22.

\section{Submit your next manuscript to BioMed Central and take full advantage of:}

- Convenient online submission

- Thorough peer review

- No space constraints or color figure charges

- Immediate publication on acceptance

- Inclusion in PubMed, CAS, Scopus and Google Scholar

- Research which is freely available for redistribution 